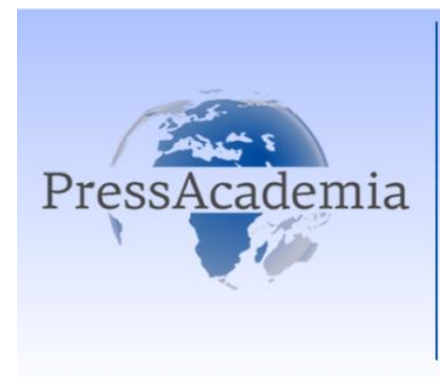

Press Academia

Procedia

2nd World Conference on Technology, Innovation and Entrepreneurship,

May 12-14, 2017, Istanbul, Turkey. Edited by Sefer Şener

\title{
TYPES OF INFORMATION TECHNOLOGY CAPABILITIES AND THEIR IMPACTS ON LOGISTICS CAPABILITIES: AN EMPIRICAL STUDY
}

\author{
DOI: 10.17261/Pressacademia.2017.517 \\ PAP-WCTIE-V.4-2017(9)-p.54-61
}

Ismail Bakan ${ }^{1}$, Zumrut Hatice Sekkeli ${ }^{2}$

${ }^{1}$ Kahramanmaraş Sütçü İmam University, ibakan63@hotmail.com

${ }^{2}$ Kahramanmaraş Sütçü Imam University, zhkiper@yahoo.com

\section{ABSTRACT}

The purpose of this study is to investigate the impacts of four components of IT capabilities on logistics capability at the logistics sector. The IT capabilities consist of IT infrastructure, IT business experience, IT relationship resources and IT human resources. The study is supported with a field study conducted on the third part logistics firms, which are members of the international forwarding associations UND, operating in 9 cities in Turkey. After distribution of 450 questionnaires, 428 usable questionnaires were returned (a response rate of 95\%). The data was analysed by using the frequency, Pearson correlation and regression analyses via SPSS programme. After analysing the research data, it was realized that there is a statistically significant relationship between four components of IT capabilities and logistics capability.
\end{abstract}

Keywords: IT capabilities, IT infrastructure, IT business experience, IT relationship resources, IT human resources, Logistics capability JEL Codes: O30, L80, M10

\section{INTRODUCTION}

Due to the rapidly changing business environment and technological improvements, companies are obliged to achieve sustainable competitive advantage in order to survive and grow. Competitive advantage may be gained from two main sources: assets and the capabilities that enable assets to be deployed advantageously (Dierickx and Cool 1989). In other words to provide a strong and sustainable competitive advantage, companies should improve organizational capabilities.

Organizational capabilities are defined as skills and abilities, complicated talents and aggregated knowledge implemented through organizational processes to coordinate activities (Zhao et., 2001:91). To be aware or not to be aware: companies are always focus on its unrivaled organizational capabilities to respond customer expectation. Organizational capabilities can be everything a company perform the best. The issue is, to find and improve activities that are done the best. If they are improved, organizational capabilities could aid small or big companies to survive in changing business environment like a life buoy.

There are too many organizational Capabilities as Process capability, Innovatioan capability, Management capability, Alliance capability, Service capability, financial capability etc. but this study is focused on two of them; Information Technology (IT) Capability and Logistics capability.

\section{LITERATURE REVIEW}

\subsection{IT Capabilities}

By acceleration of technological developments, information technology (IT) capabilities have become the most important capabilities of companies for gaining sustainable competitive advantage. Due to today's extremely competitive global business environment, companies utilize information technology to develop customer service, shorten cycle times, and decrease cost (Hwang et.al, 2015:1). 
Information technology is defined as any type of computer-based information system, including design processing and hardware, software, microcomputer applications and network investments (Zhao vd., 2001: 93). By another definition, the Information technology (IT) is the application of computers; to store, recover, dispatch and manage data, inside the firm or between firms and other ventures (https://en.wikipedia.org/wiki/Information_technology\#cite_note-DOP-1).

Information Technology (IT) can be defined as organizational IT capabilities as complicated bunches of IT-related resources, skills and collected knowledge, exercised through business processes that enable company to ordinate activities (Stoel and Muhanna, 2008: 8). Since to delineate, coordinate, combine, share and manage an organization's information assets; the IT capabilities include the human, process and technology http://www.gartner.com/it-glossary/information-capabilitiesframework/

In the literature there are many different perspectives regarding IT capabilities. The first perspective describes IT capabilities as a set of sub-dimensions such IT human capabilities and IT infrastructure capabilities, IT planning capability, system development capability, and IS operation capability (Fink 2011; Ravichandran and Lertwongsatien2005). The another perspective describes IT capability as an embracing structure that manages IT resources such as IT infrastructure, human IT resources, IT operations, IT objects and IT knowledge, IT infrastructure quality, IT business expertise, and relationship infrastructure between IT and business (Bharadwaj 2000; Tippins and Sohi 2003, cited by Xu ve Kim 2014:330). Moreover, the other perspective describes IT as a hierarchy of "composite operant resources which are IT infrastructure, IT business experience, IT relationship resources, and IT human resources". Therefore, IT capability can have as many sub dimensions as the number of different IT-related resources. (Chen and Tsou, 2012: 74).

This study focused on IT capabilities as four sub-dimensions: IT infrastructure, IT business experience, IT relationship resources and IT human resources. IT infrastructure provides the foundation for companies to deliver business applications as servers, networks, laptops, customer knowledge, help desk etc. (Aral and Weill, 2007:766). IT business experience is a company's skill to unify IT strategy with business strategy. IT relationship resources are defined as the company's ability to integrate IT functions into business units and utilize IT resources. IT human resources are the most important item of the IT asset base, and represent a strategic organizational resource and a crucial organizational capability (Chen and Tsou, 2012: 74). The scale, used for this study, is about an integrated measurement system for IT capability; that is adapted by Chen and Tsou (2012).

After scanning literature in detail, there are found many different studies regarding IT capabilities or Logistics capability. There are similar studies as "Interfirm IT capability profiles and communications for cocreating relational value: evidence from the logistics industry" (Rai., Pavlou, Im, Du, 2012) or "Information technology influences on world class logistics capability" (Closs, Goldsby, Clinton,1997) etc. But, there is not detected any study include both of these capabilities. This paper may be the first one to examine IT capability and Logistics capability together.

\subsection{Logistics Capabilities}

Logistics literature is full of instances of the effect of logistics capabilities which can provide superior contributions towards the accomplishment of superior performance and sustainable competitive advantage (Sezhian et.al, 2011:31). Logistics capabilities are defined as aptitudes, organizational processes, information and skills that allow a company to obtain high performance and sustainable competitive advantage against competitors (Mandal, 2016:44), by minimizing time and cost as much as possible. Therefore logistics capability is an exhaustive indicator of an enterprise's logistics situation (Chen et. al, 2007: 1163-1164).

In the logistics literature, there are various elements of logistics capabilities. Morash, Dröge and Vickery (1996) argue that logistics capabilities divided into two elements or "value disciplines" as "demand oriented" and "supply oriented". According Daugherty and Pittman (1995) and Fawcett, Stanley and Smith (1997) the most important item at logistics capability is the time-based capability. Also Fawcett and Fawcett (1995) declare that, to obtain optimum operational performance; these capabilities are essential; delivery speed, service quality, flexibility, cost and innovation. According to Eckert and Fawcett (1996) the most important items of logistics capabilities are human resource, quality and time; while Bowersox and Closs (1996) suggest that the most important items are responsiveness, consistency and flexibility.

Furthermore, there are various classification of logistics capabilities at logistics literature. Mentzer et al. (2004) categorize logistics capabilities; as demand management interface capability, supply management interface capability, information management capability and coordination capability. Zhao, Dröge and Stank (2001) classify logistics capabilities into customerfocused and information-focused capabilities. Lynch, Keller and Ozment (2000) argue that logistics capabilities are composed operational capability and value-added service. Shang and Marlow (2005) declare that logistics capabilities consist of information integration and general integration capabilities (Mandal, 2016:47; Lıu and Luo; 2010:50; Sezhian et.al, 2011:31).

In this study, the scale about the capabilities required to apply main activities in the business logistics are adapted by Jay JoongKun, Ozment, Sink, (2008). 


\section{RESEARCH METHODOLOGY}

\subsection{The Aim of the Study}

The aim of the study is to determine the impacts of four components of IT capabilities on logistics capability. For the study, data were collected by using the questionnaire method. Then, all questionnaire data were analysed with the Statistical Package for the Social Sciences (SPSS) for Windows. First, frequency analysis was used to indicate the respondent's opinions for each questionnaire items. Then, correlation analysis was used to find out the relationship between four components of IT capabilities and logistics capability. Finally to achieve the main aim of the study, regression analysis was performed.

\subsection{Sample and Data Collection:}

The research data was collected among managers in third part logistics (3PL) firms, which are members of the international forwarding associations, by conducting the questionnaire method. 450 questionnaires were distributed to third part logistics (3PL) firms in the 9 cities of Turkey; 428 usable questionnaires were returned and analysed.

The international forwarding associations is founded in 1974 in order to solve nationally and internationally issues. To be a member of these associations, companies must be authorized by Ministry of Transportation and must have some national and international transport certificates.

The associations have nearly 1200 members around the Turkey. Regional and urban distributions of member companies are shown at Table 1. According to regional sequencing, Marmara region has the highest number of members with 396 and Doğu Anadolu Region is the lowest region with 21 members. According to urban sequencing, istanbul has the highest number of members, with 371 and Iğdır is the lowest city with 21 members. Due to a low number of members, Iğdır has been neglected for this research. Then 428 questionnaires are distributed to 9 cities at 6 regions in Turkey, as can be seen from the Table 1 .

Table 1: Registered Companies and Distributed Questionnaires

\begin{tabular}{lllllll}
\hline Region & 1.City & $\begin{array}{l}\text { Numbers of } \\
\text { companies }\end{array}$ & 2.City & $\begin{array}{l}\text { Numbers of } \\
\text { companies }\end{array}$ & $\begin{array}{l}\text { Total number } \\
\text { of company }\end{array}$ & $\begin{array}{l}\text { Number of } \\
\text { distributed } \\
\text { questionnaires }\end{array}$ \\
\hline Marmara & İstanbul & 371 & Kocaeli & 25 & 396 & 180 \\
\hline Akdeniz & Mersin & 195 & - & - & 195 & 106 \\
\hline Karadeniz & Trabzon & 37 & Bolu & 28 & 65 & 39 \\
\hline İç Anadolu & Ankara & 47 & Kayseri & 39 & 86 & 41 \\
\hline $\begin{array}{l}\text { Güneydoğu } \\
\text { Anadolu }\end{array}$ & Gaziantep & 70 & - & - & 70 & 51 \\
\hline Ege & İzmir & 33 & - & - & 33 & 11 \\
\hline Doğu Anadolu & Iğdır & 21 & - & - & 21 & 0 \\
\hline Total & 1185 & & & & \\
\hline
\end{tabular}

\subsection{Measures of the Study Variables}

The structured questionnaire was based on academic literature. IT infrastructure, IT business experience, IT relationship resources, and IT human resources were measured by using J.-S. Chen, H.-T. Tsou (2012) scales. The multiple item scale was used for each components. Logistics capability items were taken and adapted to this study from Jay Joong-Kun Cho, John Ozment, Harry Sink, 2008. In the questionnaire respondents were asked to mention their opinions about each one. On the research questionnaire Likert-type scale is used, that ranged from (1) "strongly disagree" to (5) "strongly agree".

At the beginning, the reliability analysis was conducted. As can be seen from the Table 2 reliability coefficients for all scales exceeded .70 .

Table 2: Sample Alpha of the Study Variables.

\begin{tabular}{lll}
\hline Variables & Number of Items & Sample Alpha \\
\hline IT Infrastructure & 2 & 0,875 \\
IT Business Experience & 4 & 0,891 \\
IT Relationship Resources & 4 & 0,924 \\
\hline
\end{tabular}




\begin{tabular}{lll}
\hline IT Human Resources & 3 & 0,850 \\
Logistics capability & 11 & 0,711 \\
\hline
\end{tabular}

\section{RESEARCH MODEL AND HYPOTHESES}

The information obtained in accordance with the existing literature, the research model and hypotheses have been developed for analysis. The relationships between the four components of IT capabilities and logistics capability are illustrated in the research model (Figure 1).1

Figure 1: The Research Model

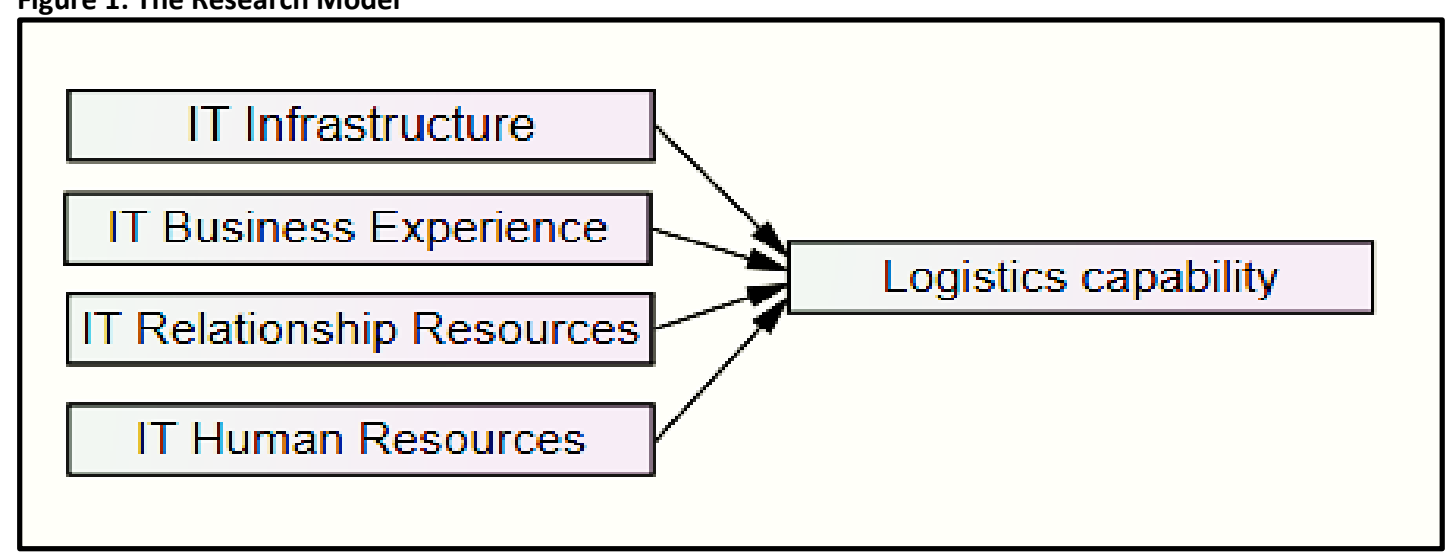

According to the research model, the following research hypotheses were defined;

H1: IT infrastructure positively influences logistics capability.

H2: IT business experience positively influences logistics capability.

H3: IT relationship resources positively influence logistics capability.

H4: IT human resources positively influence logistics capability.

\section{THE RESULTS OF THE EMPIRICAL STUDY}

\subsection{Sample Characteristics}

Table 3 shows the characteristics of the respondents and the companies participated in this study. The data was collected for this study among managers in third part logistics (3PL) firms that member of the international forwarding associations by conducting 428 questionnaires.

According to the descriptive statistics, the following information emerged. Regarding respondents' age, $24,9 \%$ were between 20-30 years old; 58,4\% were between 31 and 40, 13,4\% were between $41-50$ and the remaining 3,3\% were 51 and more. Regarding gender, $\% 85,2$ of the participants are male and $\% 14,8$ are female. When asked to their marital status, $74,6 \%$ were married, and $25,4 \%$ were single. Educational level distribution is as follows; elementary school (3,9\%), high school (62,1\%), associate degree $(12,2 \%)$, bachelor degree $(18,9 \%)$, post graduate degree $(2,6 \%)$ and doctoral degree $(0,2 \%)$.

The positions of the respondents in the firms are senior manager $(20 \%)$, middle level manager $(77,6 \%)$ and lower level manager $(2,4 \%)$. The work tenure of the respondent is under 1 year (2,6\%); 1 and 3 years $(18,6 \%), 4-6$ years $(32,5 \%), 7-9$ years $(27,1 \%)$ and more than 10 years (19.3\%).

Number of employees of the participant firms are between 10 and under is 2,6\%; $1-50$ is $78.8 \%$; $51-250$ is $16,9 \%$; $251-500$ is $1,2 \%$ and 500 and over is $1 \%$. The participant firms' capitals are the mostly local capital $(96,2 \%)$ and their commercial titles are limited (97,8\%).

\footnotetext{
${ }^{1}$ There was different variables at the modal. For this congress to shorten the article, the modal analyzed as two main parts: one of them is "IT capability and Logistics capability" and the other part is "IT capability and competitiveness". Both part includes the same demographical data.
} 
Table 3: Characteristics of Respondents and Firms

\begin{tabular}{|c|c|c|c|c|c|c|c|}
\hline & & 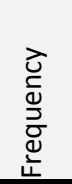 & 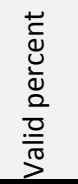 & & & 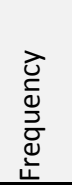 & 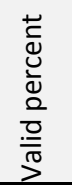 \\
\hline Gender & $\begin{array}{l}\text { Male } \\
\text { Female }\end{array}$ & $\begin{array}{l}62 \\
357\end{array}$ & $\begin{array}{l}14,8 \\
85,2\end{array}$ & Marital status & $\begin{array}{l}\text { Married } \\
\text { Single } \\
\end{array}$ & $\begin{array}{l}306 \\
104 \\
\end{array}$ & $\begin{array}{l}74,6 \\
25,4\end{array}$ \\
\hline Age & $\begin{array}{l}20-30 \\
31-40 \\
41-50 \\
51 \leq\end{array}$ & $\begin{array}{l}106 \\
249 \\
57 \\
14\end{array}$ & $\begin{array}{l}24,9 \\
58,4 \\
13,4 \\
3,3\end{array}$ & & $\begin{array}{l}\text { Elementary } \\
\text { High school } \\
\text { Associate Degree } \\
\text { Bachelor degree }\end{array}$ & $\begin{array}{l}16 \\
259 \\
51 \\
79\end{array}$ & $\begin{array}{l}3,9 \\
62,1 \\
12,2 \\
18,9\end{array}$ \\
\hline Position & \begin{tabular}{ll}
\multicolumn{2}{l}{ Senior manager } \\
Middle level \\
manager & \\
Lower & level \\
manager &
\end{tabular} & $\begin{array}{l}85 \\
330 \\
10\end{array}$ & $\begin{array}{l}20,0 \\
77,6 \\
2,4\end{array}$ & Education Level & $\begin{array}{l}\text { Post-graduate degree } \\
\text { Doctoral degree }\end{array}$ & $\begin{array}{l}11 \\
1\end{array}$ & $\begin{array}{l}2,6 \\
0,2\end{array}$ \\
\hline $\begin{array}{l}\text { Management } \\
\text { Type }\end{array}$ & $\begin{array}{l}\text { Family Members } \\
\text { Out of Family } \\
\text { Professional } \\
\text { Managers }\end{array}$ & $\begin{array}{l}366 \\
17 \\
35\end{array}$ & $\begin{array}{l}87,6 \\
4,1 \\
8,4\end{array}$ & $\begin{array}{l}\text { The Work } \\
\text { Tenure Of } \\
\text { Respondents }\end{array}$ & $\begin{array}{l}<1 \text { year } \\
1-3 \text { year } \\
4-6 \text { year } \\
7-9 \text { year } \\
10 \text { year } \leq\end{array}$ & $\begin{array}{l}11 \\
79 \\
138 \\
115 \\
82 \\
\end{array}$ & $\begin{array}{l}2,6 \\
18,6 \\
32,5 \\
27,1 \\
19,3 \\
\end{array}$ \\
\hline Establishment & $\begin{array}{l}<1 \text { year } \\
1-5 \text { year } \\
6-10 \text { year } \\
11-20 \text { year } \\
21 \text { year }<\text { up }\end{array}$ & $\begin{array}{l}1 \\
28 \\
112 \\
188 \\
93\end{array}$ & $\begin{array}{l}0,2 \\
6,6 \\
26,5 \\
44,5 \\
22,2\end{array}$ & $\begin{array}{l}\text { Number of } \\
\text { Employees }\end{array}$ & $\begin{array}{l}<10 \\
10-50 \\
51-250 \\
251-500 \\
501 \leq\end{array}$ & $\begin{array}{l}9 \\
330 \\
71 \\
5 \\
4\end{array}$ & $\begin{array}{l}2,1 \\
78,8 \\
16,9 \\
1,2 \\
1,0\end{array}$ \\
\hline $\begin{array}{l}\text { The capital } \\
\text { structure }\end{array}$ & $\begin{array}{l}\text { Local capital } \\
\text { Local\&Foreign } \\
\text { capital } \\
\text { Foreign capital }\end{array}$ & $\begin{array}{l}352 \\
7 \\
7\end{array}$ & $\begin{array}{l}96,2 \\
1,9 \\
1,9\end{array}$ & $\begin{array}{l}\text { Commercial } \\
\text { Title }\end{array}$ & $\begin{array}{l}\text { Incorporated } \\
\text { Limited } \\
\text { Unlimited }\end{array}$ & $\begin{array}{l}7 \\
398 \\
2\end{array}$ & $\begin{array}{l}1,7 \\
97,8 \\
0,5\end{array}$ \\
\hline
\end{tabular}

\subsection{Analytic Procedure (Statistical Analysis)}

At the beginning, all questionnaire data were entered into the Statistical Package for the Social Sciences (SPSS) for Windows. Then respectively in order to indicate the respondent's opinions for each questionnaire items, frequency analysis was used; to find out the relationship between four components of IT capabilities and logistics capability correlation analysis was used; at last, to achieve the main aim of the study, regression analysis was performed.

\subsection{Correlations Results}

The correlations between IT infrastructure, IT business experience, IT relationship resources, IT human resources, and Logistics capability are also covered. Table 4 depicts the correlations.

Table 4: Results of Correlation

\begin{tabular}{c|c|c|c|c|c}
\hline \multicolumn{1}{c|}{ CORRELATION } & IT Infrastructure & $\begin{array}{c}\text { IT Business } \\
\text { Experience }\end{array}$ & $\begin{array}{c}\text { IT Relationship } \\
\text { Resources }\end{array}$ & $\begin{array}{c}\text { IT Human } \\
\text { Resources }\end{array}$ & $\begin{array}{c}\text { Logistics } \\
\text { capability }\end{array}$ \\
\hline IT Infrastructure & 1 &, $844^{* *}$ &, $807^{* *}$ &, $753^{* *}$ &, $549^{* *}$ \\
\hline $\begin{array}{c}\text { IT Business } \\
\text { Experience }\end{array}$ &, $844^{* *}$ & 1 &, $904^{* *}$ &, $798^{* *}$ &, $606^{* *}$ \\
\hline $\begin{array}{c}\text { IT Relationship } \\
\text { Resources }\end{array}$ &, $807^{* *}$ &, $904^{* *}$ & 1 &, $826^{* *}$ &, $592^{* *}$ \\
\hline IT Human Resources &, $753^{* *}$ &, $798^{* *}$ &, $826^{* *}$ & 1 &, $612^{* *}$ \\
\hline Logistics capability &, $549^{* *}$ &, $606^{* *}$ &, $592^{* *}$ &, $612^{* *}$ & 1 \\
\hline
\end{tabular}


**. Correlation is significant at the 0.01 level (2-tailed).

As a result of the correlation analysis, statistically significant relationships are detected between IT infrastructure, IT business experience, IT relationship resources, IT human resources and logistics capability. The correlation coefficients in Table 4 indicate that there are strongest relationships between IT relationship resources and IT business experience $(0,904 ; p<0.01)$ and the weakest relationships between IT infrastructure and logistics capability $(0,549 ; p<0.01)$

\subsection{Regression Results of the Study}

Based on the past researches presented in the literature review, pertinent hypotheses were proposed and a model was developed. Using a linear regression analysis the theoretical model and hypotheses were tested.

\section{- IT infrastructure and logistics capability}

In the correlations analysis, a significant relation is detected between IT infrastructure and logistics capability. In order to ascertain the influence of IT infrastructure on logistics capability, regression analysis has been practiced. As shown in Table 5, the regression model is also statistically significant. The overall F-statistic of 184,076 is significant at the 0.01 level; the adjusted R-square value is 0.300 . This means that IT infrastructure explains approximately $30 \%$ of the logistics capability. Thus first hypothesis "IT infrastructure positively influences logistics capability" $(H 1)$ is supported.

Table 5: IT infrastructure and logistics capability

\begin{tabular}{lllllll}
\hline Independent variable & $\boldsymbol{\beta}$ & $\mathbf{t}$ & $\mathbf{p}$ & $\mathbf{R}^{2}$ & ${\text { Adjusted } \mathbf{R}^{2}}^{2}$ & $\mathbf{F}$ \\
\hline IT Infrastructure(ITI) & 0,549 & 13,567 & 0,00 & 0,302 & 0,30 & 184,076 \\
\hline
\end{tabular}

Dependent variable: Logistics capability ${ }^{*} p<0,001$

- IT business experience and logistics capability

As a result of the regression analysis, the model is significant with $\mathrm{F}$ value of $246,695(\mathrm{p}<0.01)$ and explained $36,5 \%$ of the logistics capability by the adjusted $\mathrm{R}^{2}$ value. Hence, hypothesis H2: "IT business experience positively influences logistics capability" is supported.

Table 6: IT business experience and logistics capability

\begin{tabular}{lllllll}
\hline Independent variable & $\boldsymbol{\beta}$ & $\mathbf{t}$ & $\mathbf{p}$ & $\mathbf{R}^{2}$ & ${\text { Adjusted } \mathbf{R}^{2}}^{2}$ & $\mathbf{F}$ \\
\hline IT Business Experience(ITBE) & 0,606 & 15,707 & 0,00 & 0,367 & 0,365 & 246,695 \\
\hline
\end{tabular}

Dependent variable: Logistics capability ${ }^{*} p<0,001$

\section{- IT relationship resources and logistics capability}

Another regression test was conducted to determine the effect of IT Relationship Resources (ITRR) on logistics capability. The regression results show that ITRR and Logistics capability received contribute significantly, with an overall F value of 228.542 $(p<0.01)$, and; the adjusted R-square value is 0.349 . This means that IT infrastructure explains approximately $34,9 \%$ of the logistics capability. Thus, hypothesis H3 is supported.

Table 7._IT relationship resources and logistics capability

\begin{tabular}{lllllll}
\hline Independent variable & $\boldsymbol{\beta}$ & $\mathbf{t}$ & $\mathbf{p}$ & $\mathbf{R}^{2}$ & ${\text { Adjusted } \mathbf{R}^{2}}$ & $\mathbf{F}$ \\
\hline IT Relationship Resources (ITRR) & 0,592 & 15,118 & 0,00 & 0,350 & 0,349 & 228,542 \\
\hline
\end{tabular}

Dependent variable: Logistics capability ${ }^{*} p<0,001$ 


\section{- IT human resources and logistics capability}

In the correlations analysis, a significant relation is detected between IT human resource and logistics capability. In order to examine the effect of IT infrastructure on logistics capability, regression analysis has been implemented. As shown in Table 8, the regression model is also statistically significant. The overall F-statistic of 253,858 is significant at the 0.01 level. Because of the adjusted R-square value $(0,373)$, IT infrastructure explains nearly $37,3 \%$ of the logistics capability. Thus the last hypothesis of "IT human resources positively effects on logistics capability"(H4) is supported.

Table 8: IT human resources and logistics capability

\begin{tabular}{llcllll}
\hline Independent variable & $\boldsymbol{\beta}$ & $\mathbf{t}$ & $\mathbf{p}$ & $\mathbf{R}^{2}$ & ${\text { Adjusted } \mathbf{R}^{2}}^{2}$ & $\mathbf{F}$ \\
\hline IT Human Resources (ITHR) & 0,612 & 15,933 & 0,00 & 0,375 & 0,373 & 253,858 \\
\hline
\end{tabular}

Dependent variable: Logisticscapability * $p<0,001$

\section{CONCLUSION}

The effects of IT Capabilities on Logistics capabilities were analysed by this empirical study. The data was collected by using the questionnaire as the method for data collection. In this study, IT capabilities (by Chen and Tsou, 2012) were used to determine the impact on Logistics capabilities within the 3PL companies in Turkey. The scale for IT Capabilities have four dimensions called IT infrastructure, IT business experience, IT relationship resources and IT human resources. After analysing the empirical data, it is found out that a company's IT capability has a superior effect on logistics capabilities, indisputably. Among the four dimensions of IT capabilities, IT human resources is the most effective factor $(37,3 \%)$ and IT infrastructure is the less effective factor (\%30) regarding their effects on logistics capabilities. IT capability is the most important strategic resources for companies in information-intensive industries which will directly enhance the efficiency of logistics capabilities. Due to the effects of IT capabilities onlogistics capabilities, managers must invest in IT capabilities, if they want to achieve competitive advantage at global competition.

As in every research studies, this study also has some limitations. We directed our questionnaire at 3PL managers because they were the best positioned to answer questions related to the technology management and their effects on logistics capabilities. Thus, the results may not be sensitive enough. Future research can collect the data from the IT managers that work at logistics sector; and by using this data the results will be more sensitive. Also, the present study was conducted 3PL firms among 9 cities in Turkey. Future studies should examine 3PL firms in other cities in Turkey and in the other countries to increase the generalization of the model.

\section{REFERENCES}

Aral, S., Weill, P. 2007, "IT Assets, Organizational Capabilities, and Firm Performance: How Resource Allocations and Organizational Differences Explain Performance Variation". Organization Science, 18(5), 763-780.

Bharadwaj, A. S. 2000, "A Resource-Based Perspective on Information Technology Capability and Firm Performance: An Empirical Investigation". MIS quarterly, 169-196.

Bowersox And Bowersox, D. J., Closs, D. J., Helferich, O. K. 1996, “Logistical management “,(Vol. 6). New York, NY: McGraw-Hill.

Chen, J. S., Tsou, H. T. 2012, "Performance effects of IT capability, service process innovation, and the mediating role of customer service". Journal of Engineering and Technology Management, 29(1), 71-94.

Chen, R., Liu, L., Wu, J., 2007, (November), "Logistics Capability and Its Grey Assessment Model”. In Grey Systems and Intelligent Services, 2007. GSIS 2007. IEEE International Conference on (pp. 1163-1167). IEEE.

Closs, D. J., Goldsby, T. J., Clinton, S. R. 1997, "Information Technology Influences On World Class Logistics Capability". International Journal of Physical Distribution \& Logistics Management, 27(1), 4-17.

Daugherty, P. J., \& Pittman, P. H. 1995, "Utilization of Time-Based Strategies: Creating Distribution Flexibility/Responsiveness". International Journal of Operations \& Production Management, 15(2), 54-60.

Dierickx, I., Cool, K. 1989, “Asset Stock Accumulation and the Sustainability Of Competitive Advantage: Reply”. Management Science, 35(12). 
Eckert, J.A. and Fawcett, S.J. 199), "Critical Capability for Logistics Excellence: People, Quality, and Time”, Proceedings of the Council of Logistics Management, pp. 183-97.

Fawcett, S. E., Stanley, L. L., Smith, S. R. 1997. "Developing a logistics capability to improve the performance of international operations". Journal of business logistics, 18(2), 101.

Fawcett, S.E. and Fawcett, S.A. 1995, "The Firm as A Value-Added System: Integrating Logistics, Operations and Purchasing", International Journal of Physical Distribution and Logistics Management, Vol. 25, No. 5, pp.24-42

Fink, L. 2011, "How Do IT Capabilities Create Strategic Value? Toward Greater Integration of Insights from Reductionistic and Holistic Approaches". European Journal of Information Systems, 20(1), 16-33.

Hwang, D., Yang, M. G. M., Hong, P., 2015. “Mediating Effect of IT-Enabled Capabilities on Competitive Performance Outcomes: An Empirical Investigation of ERP Implementation". Journal of Engineering and Technology Management, 36, 1-23.

Joong-Kun Cho, J., Ozment, J., Sink, H. 2008. "Logistics Capability, Logistics Outsourcing and Firm Performance in an E-Commerce Market". International journal of physical distribution \& logistics management, 38(5), 336-359.

Liu, L., Luo, D. 2012, "Effects of Logistics Capabilities on Performance in Manufacturing Firms". Contemporary Logistics, (9), 8.

Lynch, D. F., Keller, S. B., Ozment, J. 2000. "The Effects of Logistics Capabilities and Strategy on Firm Performance". Journal of business logistics, 21(2), 47.

Mandal, S. 2016, "Towards An Integrated Logistics Capabilities Model Of Supply Chain Flexibility: A Social Exchange Perspective". Romanian Economic and Business Review, 11(3), 44.

Mentzer, John T. and Williams, Lisa R. 2001, "The Role of Logistics Leverage in Marketing Strategy," Journal of Marketing Channels, 8 (3), pp. 2947.

Morash, E. A., Droge, C.L. M. and Vickery, S.K. 1996, "Strategic Logistics Capabilities for Competitive Advantage and Firm Success." Journal of Business Logistics, Vol 17, No 1, pp. 1-22.

Rai, A., Pavlou, P. A., Im, G., Du, S. 2012, “Interfirm IT Capability Profiles And Communications For Cocreating Relational Value: Evidence From The Logistics Industry". MIS quarterly, 36(1), 233-262.

Sezhiyan, D. M., Page, T., Iskanius, P.2011, "The Impact of Supply Effort Management, Logistics Capability, and Supply Chain Management Strategies on Firm Performance". International Journal of Electronic Transport, 1(1), 26-44.

Shang, K. C., Marlow, P. B. 2005, "Logistics Capability and Performance in Taiwan's Major Manufacturing Firms". Transportation Research Part E: Logistics and Transportation Review, 41(3), 217-234.

Stoel, M. D., \& Muhanna, W. A. 2009, "IT Capabilities And Firm Performance: A Contingency Analysis Of The Role Of Industry And IT Capability Type". Information \& Management, 46(3), 181-189.

Tippins, M. J., Sohi, R. S. 2003, “IT competency and firm performance: is organizational learning a missing link?" Strategic management journal, 24(8), 745-761.,

Xu, P., Jongwoo (Jonathan) Kim, 2014, “Achieving Dynamic Capabilities with Business Intelligence”, In PACIS (p. 330).

Zhao M, Dröge C and Stank T. 2001, "The Effects of Logistics Capabilities on Firm Performance: Customer-Focused Versus Information-Focused Capabilities", Journal of Business Logistics, 22(2), 91-107.

http://www.gartner.com/it-glossary/information-capabilities-framework

https://en.wikipedia.org/wiki/information technology\#cite note-dop-1. 